\title{
HYDROLOGIC ENVIRONMENT OF THE SILURIAN SALT DEPOSITS IN PARTS OF MICHIGAN, OHIO, AND NEW YORK
}

\section{U.S. GEOLOGICAL SURVEY •}

Open-File Report 78-684

Prepared in cooperation with U.S. Department of Energy

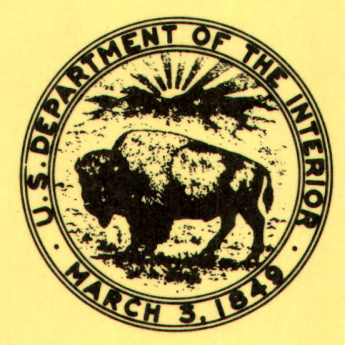





\section{UNITED STATES \\ DEPARTHENT OF THE INTERIOR}

GEOLOGICAL SURVEY

HYDROLOGIC ENVIRONMENT OP THE SILURIAN SALT DEPOSITS IN PARTS OF MICHIGAN, OHIO, AND NEW YORK By Stanley E. Norris

Dpen-File Report 78-684

Prepared in cooperation ith

U.S. Department of Energy

Colunbus, Ohio

Juae 1978 


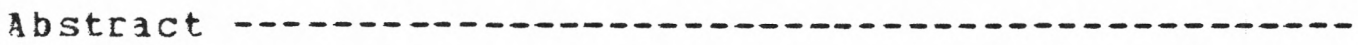

Introduction

Dccurrence of the salt deposits

Fluid environment of the salt deposits --- - - - - -

Evidence of dissolution -

Areas suggestel for additional investigation -- - - -

ILLUSTRATIONS

Figure 1 Extent of the Silurian salt deposits in Michigan, Ohio, New York, and

adjacent states - - -

2 Altitude of drillers' "first water" zone (Jriskany sandstone) (top map) and Newberg or "second water" zone (bottom ap) in northeast ohio

3 Aggregate thickness of salt, gypsum, and anhydrite beds greater than 10 feet thick in the Salina Formation in Michigan -.-

4 Geologic section in northern Michigan, shoving occurrence of evaporites in the Salina Formation - 


\section{ILLUSTRATIONS}

Page

Pigure 5 seologic section in southern

Michigan, showing occurrence of

evaporites in the Salina pormation -----

6 Agragate thickness of salt beds in the

Salina Formation in northoast Ohio - - -

7 Geologic section in Lake and

Ashtabula Counties, Ohio, showing salt

beds in the Salina Fornation -

8 Geologic section from Medina to

Ashtabula Counties, Ohio, showing salt

beds in the Salina formation

9 Aggrequte thickness of salt beds in the

Syracuse Salt of Salina Group in western

Naw York -

10 Jeologic section from Cayuga to

Tioga Counties, New York, showing

salt beds in the Salina Group -

11 Geologic section in Onandaga and

cortland, and Broome Counties, New York showing salt beds in the saliaa Group -- 


\section{ABSTRACT}

The aggregate thickness of evaporites (salt, gypsun, and anhydrite) in the silurian salina sequence in Michigan exceeds 1200 feet in areas near the periphery of the Michigan basin, where the salt beds are less than 3000 feet below land surface. In northeast ohio the aggregate thickness of salt beds is as much as 200 feet in places, and in vestern New York it is more than 500 feet, where the beds are less than 3000 feet deep.

The salt-bearing rocks dip regionally on the order of 50 feet per mile; those in Michigan dip tovard the center of the Michigan basin, and those in ohio and Nev York, in the Appalachian basin, dip generally southward. The rocks in both basins thicken downdip. Minor folds and faults occur in the salt-bearing rocks in all three states. Some of this defornation has been attenuated or absorbed by the salt beds.

Occurring near the middle of thick sedimentary sequences, the salt beds are bounded above and below by beds containing ater having dissolved-solids concentrations several times that of seawater. The brines occur comonly in discrete zones of high peraeability at specific places in the stratigraphic sequence.

In northeast ohio two prominent brine zones are recognized by the driller, the Deyonian Oriskany Sandstone. or "first water" zone, above the Salina Formation, and the Neuburg or "sezond water" zone belov the Salina. In each aquifer there is a vertical component of hydraulic head, but little brine probably oves through the salt beds because their permeability is extremely loy. Also, there is little evidence of dissolution of the salt in areas distant fron the outcrop, suggesting that if brine does nove through the salt, wovenent is at a slow enough rate so that, in combination with the saturated or near-saturated condition of the water, it precludes significant dissolution. Principal brine wovement is probably in the permeable zones in the direction of the hydraulic gradient.

Tyo areas in Michigan and one area each in ohio and New York appear suitable for additional investigation of the salt beds for purposes of radioactive waste disposal. One of 
the Michigan areas is in the northern part of the southern peninsula, in Presque Isle and Alpena Counties; the other is in the southern part of the southern peninsula, in Oakland, Macomb, and St. Clair counties (fig. 3). In northeast Ohio the area that appears to be suitable for investigation includes most of the eastern half of Lake county and extends eastward into Ashtabula county and southward into Geauga county. In western New York conditions may warrant additional investigation in Schuyler, Tompkins, and western Cortland Counties.

\section{INTRODUCTION}

In February 1976 the U.S. Department of Energy (DOE), announced a greatly expanded program for managing radioactive waste of defense and commercial origin. The commercial radioactive waste disposal program, which was named the National Naste Terminal Storage (NWTS) program, represents the principal programmatic effort of DOE for ultimate and final disposal of commercial radioactive waste. The U.S. Geological Survey, under the provision of interagency agreement no. EY-76-C-05-4339, is participating in the NHTS program by conducting studies of geologic formations of interest and by providing information on their properties and characteristics. This work is coordinated by the U.S. Geological Survey, Reston, Virginia, and the U.S. Dept. of Energy, Oak Ridge, Tennessee.

This report describes the geologic framework and fluid environment of the Silurian salt deposits in Michigan, Ohio, and New York, and is based largely on a literature review. special emphasis is given to areas where the salt deposits are generally less than 3000 feet deep.

The author acknowledges the work of 0 . J. Cosner and Julian Soren in New York, J. R. Stark and R. C. Hinkle in Michigan, and T. M. Crouch in Ohio: they compiled the geologic and hydrologic data in their respective states.

The focus of the investigation was on the hydrology of the deeply buried rocks associated with salt beds, but comparatively little hydrologic information is available 
from published sources. Some data on the occurrence of deep-seated brine zones have been obtained, however, and the levels to wich brine rises in deep wells are reported from scattered locations based on selected logs of oil and gas wells.

\section{OCCURRENCE OP THE SALT DEPOSITS}

The Silurian salt deposits in Michigan, Ohio and New York are near the midale of a thick sequence of Paleozoic sedimentary rocks that were laid down in the Michigan and Appalachian basins (fig. 1). These basins were at times connected, as shown by the continuity of some of the beds. In both, the sequence of sedimentary rocks consists of, in general, a lover section predominately of sandstone and shale with some dolomite, a middle section that is principally carbonates and evaporites and includes the saltbearing beds, and an upper section that is ostly shale and sandstone.

The Michigan basin is a nearly circular, bowl-like structure centering near Saginaw Bay in the southern peninsula (fig. 3). The regional dip of the rocks is 25 to 60 feet per mile toward the center of the basin. The Silurian Salina Pormation $r$ anges in thickness from 0 at the periphery of the basin to about 4500 feet near its center, were the top of the salt-bearing sequence is more than 6500 feet deep. The salt beds are less than 3000 feet below the surface near the edges of the basin in both the northern and southern parts of the southern peninsula.

In Michigan, the Salina Formation is divided into seven units designated. from oldest to youngest, A through $G$ (Landes, 1945). In general, there are three shaly units (C, E, G), three salt units (B, D, F), and a basal dolomite (A) which also contains salt. The aggregate thickness of the evaporites (salt, gypsum, and anhydrite) within the salina sequence is about 2000 feet near the center of the basin. In areas where the salt beds are less than 3000 feet deep the aggregate thickness is about 1200 feet in places (fig. 3). The shallower beds are mostly the A, B, and F units. 


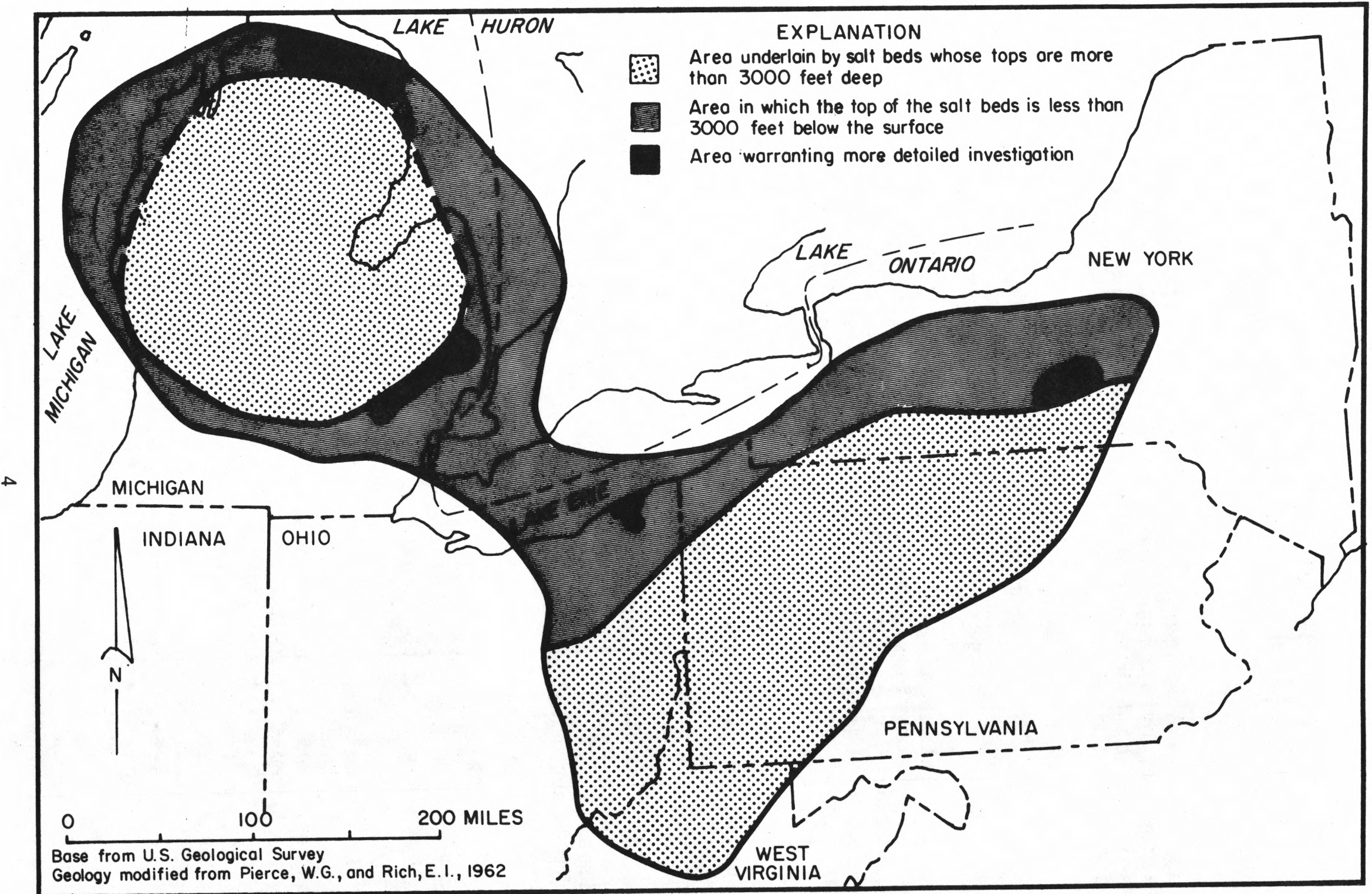

Figure 1.--Extent of the Silurian salt deposits in Michigan, Ohio, New York, and adjacent states. 
Folding and faulting may have affected the salt-bearing rocks in Michigan. In southeastern Michigan is the 70-mile long Howell anticline, which, together with several associated folds. comprise the washtenaw anticlinorium (E11s, 1969). Another large fold is the 80-mile long Freedom anticline near the Ohio line.

On the west side of the Howell anticline is a large fault, with a vertical displacement of about 1000 feet. Another fault may occur along the west side of the Freedom anticline. Small faults occur near outcrops of rocks that formerly contained soluble evaporites. These faults are caused by the dissolutioning of the evaporites and subsequent collapse of the overlying rocks.

In Ohio, the Salina Formation occurs near the base of a 1500-foot section of carbonate rocks, known to the driller as the "Big lime." The salt-bearing rocks here are on the northwest flank of the Appalachian basin and dip 30 to 50 feet per mile to the southeast, descending from sea level in Lorain county to about 3000 feet below sea level near the Pennsylvania line, in southeast Mahoning County: The salt beds are less than 3000 feet deep in all, or parts of, 11 counties in the vicinity of Lake Erie.

The Salina Formation is composed chiefly of dolomite and shale, interbedded with anhydrite, gypsum, and salt. The Salina is about 750 feet thick near Lake Erie and thickens southeastward to about 1000 feet in northeast Ohio. Individual salt beds generally are less than 50 feet thick; a few beds are as much as 100 feet thick. The aggregate thickness of the salt beds is generally less than 200 feet (fig. 6).

The classification system used in Michigan has been extended into Ohio, where units A through G of the Salina Formation are recognized. Salt does not occur in the A and $G$ units in Ohio, and occurs only sparingly in the $C$ unit. The $G$ unit, however, contains a thick anhydrite section. The B unit contains salts that are thinly bedded and impure. The thickest single bed in the $B$ unit rarely exceeds 10 feet in thickness in ohio. 
Salt of the $D$ unit is used for artificial brine production in Lake and summit Counties. Clifford (1973, p. 8) reports that the $D$ salt is as much as 40 feet thick near Lake Erie and may be shallow enough to mine, but indications are that it may be too coarsely crystalline and friable to provide good roof support.

Salts of the $E$ unit are generally less than 20 feet thick in areas where the top salt bed is less than 3000 feet below the surface, and they are of little commercial importance except possibly where they can be extracted in conjunction with the F-unit salts.

Salts of the $F$ unit are the most important salt beds in Ohio. Four major salt bodies occur within the $F$ unit, designated F1 through F4, in ascending order. The F1 salt, which is mined at Fairport Harbor in Ashtabula county, at a depth of 1920 feet by the Morton Salt Co., is the most widespread of the $F$ salts. It ranges generally from 50 to 80 feet in thickness.

The F2 salt is mined in Cuyahoga county, at the waterfront in Cleveland, at a depth of 1713 feet by the International salt Co. Here the salt is separated by a 6foot layer of anhydrite into an "A" bed above and a "B" bed below. The "A" bed is 21 feet thick; the "B" bed, which is being mined, is 46 feet thick. F3 and F4 salts are thin and of very limited areal extent within the area where the top salt bed is less than 3000 feet deep.

The salt beds and associated strata in eastern Ohio have been subjected to structural deformation, including flowage, bending and fracturing. Frank (1963) cites evidence in cores from two wells near Painesville, Lake County, of salt intrusion, features of which he compares with intruded salt plugs of the Guif coast.

\section{Clifford (1972, p. 2107-2108) states:}

"Four distinct types of salt involvement are identified in Ohio: thin-skinned thrusting along salt beds (southern Ohio), salt-flowage structure (Columbiana County), solution-collapse structure (Ashtabula County). and drape over preexisting structure (summit and stark counties)." 
A structure map by Janssens (1977, fig. 8) of a 6-county area in northeast ohio, shows a faut in southern portage county. The fault is parallel to the regional dip and is upthrown on the northeast side.

Jacoby (1970) describes two faults in the salt mine at cleveland. One fault has a displacement of 4 to 4.5 feet; the other has 57 feet of displacement. Associated with the fault system are "floor heave, roof slabbing, and pillar spalling."

In New York, rocks of the Salina Group, as the Salina sequence is termed, crop out in a narrow band approximately parallel to the south shore of Lake ontario. The rocks here are on the northwest flank of the Appalachian basin and dip generally southward 50 to 60 feet per mile, dipping from the outcrop to about 3600 feet below sea level near the Pennsylvania line. The Salina Group rocks thicken from about 400 to 2500 feet as they deepen. The salt beds are less than 3000 feet deep in most of the region between lake Ontario and the Pennsylvania line (fig. 9).

The Salina Group in New York is divided into four Formations termed (ascending), the Vernon Shale, syracuse Salt, Camillus Shale, and Bertie Limestone. Salt beds occur only in the syracuse and the lower two-thirds of the Vernon (Rickard, 1969, p. 4).

The syracuse salt is commercially the most important salt deposit in New York. Rickard (1969, p. 14) reports that salt is produced from brine wells near Tully, in southern onondago county, and near watkins Glen in schuyler county. The salt is mined at Myers by the Cayuga Rock Salt co.. Inc., and formerly was extracted through brine wells at Ludlowville, both places being a few miles north of Ithaca in northern Tompkins county.

The syracuse salt can be traced into the Michigan basin where it corresponds to Salina units $D, E$, and part of $F$. The salt beds of the syracuse are interbedded with gray and greenish-gray shales, dolomite, and anhydrite. In aggregate thickness the salt beds range from 0 to more than 500 feet. 
attaining their maximum thickness in chemung, Tioga, Schuyler, and Tompkins counties, in the vicinity of Ithaca and Elmira (fig. 10).

Salt beds in the vernon shale range in aggregate thickness from 0 to more than 50 feet, attaining their maximum thickness in Allegany, Livingston, and Wyoming Counties. The Vernon can be traced westward across Ontario into Michigan where it corresponds to units $A, B$, and C of the Michigan basin Salina sequence.

Salt of the Vernon shale, unit $B$, is mined at Retsof, Livingston county, and is the probable source of artificial brine extracted at silver springs, in wyoming county (Rickard, 1969, p. 8).

Small local folds and a few faults occur in western New York. Some faults extend into the salt beds, as shown by drill core evidence of brecciation and the presence of shale and dolomite fragments within the salt. The clarendonLinden fault is depicted as a zone of faults extending northward from northwestern Allegany county through the eastern part of orleans county. The faulted zone is shown by Van Tyne (1977. Item 7) to contain reverse and normal faults with horst- and graben-like features (upthrust and down-dropped blocks, respectively) between faults. As shown by Van Tyne, the faults do not extend to land surface, but may displace rocks 10 to 200 feet in formations below the Salina Group. Van Tyne's interpretation of the vertical discontinuity of the fault zone is that the salt and shale beds in the salina have absorbed large-scale faulting, causing the faults to pass upward into folds (Van Tyne, 1977, p. 8-9).

\section{FLUID ENVIRONMENT OF THE SALT DEPOSITS}

In Michigan, Ohio, and New York the salt beds are surrounded by highly mineralized waters, typically saturated or nearly so, having dissolved-solids concentrations several times that of seawater. Sodium and chloride are the most abundant ions in the brines, with significant concentrations also of calcium and magnesium. 
Brines occur typically in discrete zones of relatively high permeability, at specific places in the stratigraphic sequence. Many such permeable zones, recognized generally by drillers of oil and gas wells, are commonly reported on we1l logs. The brines are below the fresh-water aquifers.

In Michigan three chemical zones have been defined--an upper zone of good-quality water in the glacial deposits and shallow bedrock, a lower zone mostly of brine, and a transition zone separating the upper and lower zones (Piper, 1972). Water in the transition zone varies from freshwater to brine, becoming more mineralized with depth. The upper boundary of the transition zone is the upper level to which the underlying brines have ascended to mix with the overlying freshwater. The lower boundary of this zone coincides with the greatest depth to which recent meteoric water has percolated (Piper, 1972).

A similar tri-part separation of the ground waters could also be used in describing conditions in Ohio and New York. The concept suggests the presence of two essentially independent circulatory systems, a shallow system for the meteoric waters and a deep system for the brines. A corollary requirement is that the brines originated as pore waters and their composition and ion concentration were changed by ion-sieving processes accompanying compaction, lithification, and pore water expulsion during the many millions of years since the sediments were laid down.

An alternative concept of deep-basin hydrology is given by Bredehoeft and others (1963), who explain the origin of brines by the same ion-sieving processes but postulate deep circulation of meteoric waters. Noting that in areas distant from the outcrop the hydraulic head typically increases with depth, the authors state that the water moves upward and, of necessity, must pass through relatively impermeable clay or shale layers that separate the more permeable zones. They describe a mechanism by which highly concentrated brines can be formed by passage of water through the clay or shale layers, which act as semipermeable membranes that selectively restrict and permit the passage of ions. Both processes explain why the concentrations of dissolved ions typically increase with depth. The deep 
circulation of meteoric water provides for a continuing concentration mechanism that might continue long after compaction and expulsion of free pore water have occurred. Also, it does not require the initial presence in the sediments of marine saline water to account for the brines.

The model of Bredehoeft and others (1963) was devised for the Illinois basin, which contains no bedded salt deposits. The model appears less applicable to the Michigan and Appalachian basins because of the presence there of the thick beds of salt and anhydrite. These deposits, because of their very low permeability, must greatly restrict the deep circulation of meteoric waters. In support of the hypothesis, however, clayton and others (1966) present isotopic evidence to show that some water molecules in brines from both the Illinois and Michigan basins originated as fresh water.

In Ohio, the lowest brine zone is in Cambrian rocks that are equivalent to the "Mt. Simon Sandstone," at the base of the sedimentary sequence. The "Mt. Simon" is an important aquifer in the Chicago-Milwaukee area, but in Ohio contains highly mineralized water and is used chiefly for disposal of industrial wastes. Clifford (1975) reports that seven disposal wells in the "Mt. Simon" were being used in 1974 in Ohio, and presents a highly generalized map of the potentiometric surface, showing the probable direction of water movement. In northeast ohio the flow is to the northwest, toward a potentiometric low in western Ohio whose long axis coincides approximately with that of the Cincinnati arch. Clifford states that head differences average about 3 feet per mile and flow velocities amount to only a few inches per year.

The salinity of the water in the "Mt. Simon Sandstone" increases with depth. Dissolved solids content is about $200.000 \mathrm{p} / \mathrm{m}$ (parts per million) in central Ohio and increases to more than $300,000 \mathrm{p} / \mathrm{m}$ downdip in eastern Ohio (clifford, 1975, figs. 12 and 13).

Two of the most widely recognized brine zones in ohio are the Newburg zone, in the Lockport Dolomite, immediately underlying the Salina Formation, and the Qriskany Sandstone 
or its equivalent, above the Salina. The Newburg is described by stout and others (1932, p. 26-27) as

"one of the chief water-bearing horizons in the deepseated rocks. The $f l c w$ is so great that it is known to the drillers as the 'Big water in the Big lime.' It is also commonly referred to as the 'Second water.' Brines at this horizon are widely distributed; in fact they are seldom wanting in any part of the eastern half of Ohio."

Analyses of water from about 40 wells in the Newburg is given by stout and others (1932) and Lamborn (1952). Dissolved solids fall mostly in the range of 250,000 to $350,000 \mathrm{mg} / \mathrm{L}$ (milligrams per liter); the highest reported was $528,724 \mathrm{mg} / \mathrm{L}$, from a well 2955 feet deep in Perry County, about 40 miles east of Columbus.

The oriskany Sandstone, which occurs about 250 feet above the Salina Formation at cleveland, is the source of the "first water" in the "Big lime." Brine in the Oriskany, or at the horizon where the oriskany is missing from the geologic column, is also highly concentrated. Stout and others (1932), and Lamborn (1952), give a combined list of 18 analyses of samples of the "first water" from wells in northeast Ohio. Dissolved solids range from 134,000 to $391,000 \mathrm{mg} / \mathrm{L}$; most values are between about 225,000 and $250,000 \mathrm{mg} / \mathrm{L}$.

The fact that dissolved-solids concentrations in the Newburg are, on average, higher than those in the shallower oriskany sandstone, could support the hypothesis that the brines originated by membrane filtering of meteoric water as suggested by Bredehoeft and others (1963).

Figure 2 shows contours on the "first water" and "second water" zones in northeast ohio. The contours on both maps in fig. 2 are similar and closely resemble geologic structure maps of the area (Clifford, 1973, pls. 2 and 3), showing that these brines occupy porous and permeable zones in the stratigraphic column, with depths readily predictable at different places.

Little information is available from the drillers' logs relative to the potentiometric levels in these wells, or the 


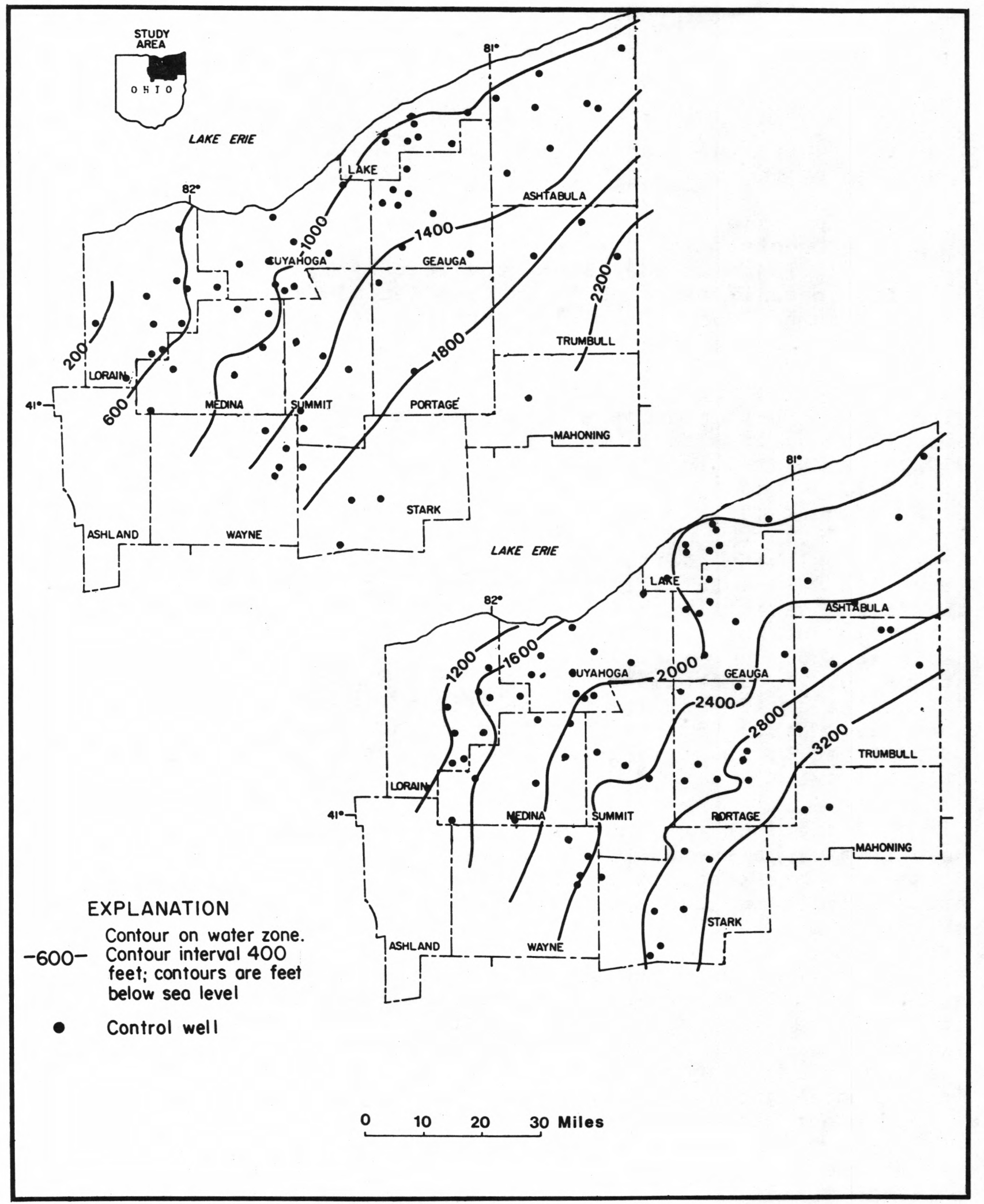

Figure 2.--Altitude of drillers' "first water" zone (Oriskany Sandstone) (top map) and Newburg or "second water" zone (bottom map) in northeast Ohio. 
direction of water movement. On only three logs, of about 90 used to determine the depth to the Newburg zone, was the height to which the water rose in the well reported. In two wells in Lorain county the water rose to within 100 and 200 feet of the surface from water zones reached at depths of 2300 and 2190 feet, respectively. In a well in Medina County the water rose to within 700 feet of the surface, from a water zone 3390 feet deep. Based on these data the apparent slope of the potentiometric surface is to the east.

Of about 70 logs used to determine the depth to the "first water" zone, only seven recorded the level to which water rose in the drill hole. The potentiometric surface in four wells in Lorain county ranged from 359 to 489 feet above sea level. In two wells in Medina County it ranged from 336 to 487 feet above sea level, and it was 425 feet above sea level in a well in lake county. The regional slope of the potentiometric surface could not be determined from these data.

The specific gravity of brine is higher than that of fresh water, and the observed head in brine wells may be significantly lower than that in equivalent fresh-water wells. For example, on the log of a well drilled near Barberton, Ohio, the driller reported "bittern" water in the Oriskany Sandstone at the depth of 2532 feet. The depth to water was given as "150 feet from top of hole." The report does not indicate whether this level represented the head of the natural water in the oriskany sandstone or whether water or brine may have been added to the hole in the drilling process. If it is assumed that it was the natural brine, having a specific gravity, say, of 1.2 , the equivalent fresh-water head in the Oriskany Sandstone was 326 feet above land surface at this location at the time the well was drilled.

Deep-seated zones of high permeability, similar to those described in Ohio, occur also in Michigan and New York. In Michigan, logs of gas and oil wells record $z$ cnes of lost circulation in the Devonian Traverse Group and Dundee Limestone, Detroit River Group, Bois Blanc Formation and the Silurian Salina Formation (B, C, and F units), and Niagara Group. Water zones are noted in the Traverse Grcup, Detroit 
River Group, Dundee Formation and Salina Formation (A-1 Carbonate). No information is provided in the logs on the static water level in these wells.

In New York, permeable zones parallel with the bedding have been identified in outcrops of the lockport Dolomite in the Niagara Palls area (Johnston, R. H., 1964), and it seems probable that these or similar zones also exist where the unit is deeply buried. Widespread permeable zones likely exist at other places in the stratigraphic sequence in New York, as they do in Michigan and Ohio.

\section{EVIDENCE OF DISSOLUTION}

A question in the use of salt beds for waste containment is "how does dissolutioning affect the salt beds?" What effect has it had in the geologic past, and how might it affect the deposits in the future in, say, the next halfmillion years, in an environment likely to be chosen for disposal? A disposal site is not likely to be selected close to the margins of the salt beds, especially where the bels are at shallow depths. However, most evidence of dissolutioning appearing in the literature suggests that it has taken place at shallow depth, usually involving recession of formation boundaries. Discharge of salt springs near outcrop areas, and surface collapse features, are among the effects commonly reported.

In Michigan, prominent exposures of collapse structures and brecciated rocks occur in the outcrop area of the salina Formation in the northern part of the southern peninsula and the eastern part of the northern peninsula. The fragments of rocks in this breccia, the Mackinac Breccia, are from rock units ranging from the Salina Formation to the Detroit River Group (Landes, 1959). The collapse structures and brecciated rocks resulted when the roofs of caverns and caves, formed when evaporites in the Salina Formation were dissolved by ground water, collapsed. No evidence of collapse or sinking exists in the underlying Niagaran rocks.

Also in Michigan, the D and F Evaporite units of the Salina Formation are missing in parts of Macomb county (fig. 
3) near the outcrop area. Their absence is attributed to dissolution by ground water. Dissolution also may be responsible for the wedging out of the $B$ and $F$ Evaporites in Wayne County and of the F Evaporite in Alpena and presque Isle counties (Landes, 1945). These areas also are relatively close to the Salina outcrop.

Salt-core anticlines, composed of lenticular lenses of Salina salt, are common in Michigan. Most of these anticlines are related to salt in the A-1 Evaporite and are attributed to the removal of surrounding adjacent salt by circulating ground water (Ells, 1967). Additional subsurface data, such as abnormal and variable dips of dolomites and shales in the Salina, and fractures and joints filled with halite, are further evidence of the leaching of salts by circulating ground water.

In Ohio and New York, in areas extending from the Salina outcrop to where the formation units are several hundred feet below land surface, no salt beds are present, and it must be assumed that the salt was dissolved by circulating fresh ground water. Salty springs in Cayuga County, New York, used for commercial salt production in the early 1800 's, and brines reported in shallow wells in Jswego, Chautauqua, and Onondaga Counties, New York, are further evidence of the leaching of salt beds near the cutcrop.

Evidence of dissolutioning in areas away from the outcrop where salt beds are relatively deep, also is reported in the literature. However, much of this dissolutioning may have occurred early in geologic time and may not be occurring at present, according to stehli, Namy, and Aten (1963), who state, with reference to the deeper beds in Ohio:

"Comparison of halite isopachs with total Salina isopachs and with structural maps suggests much loss of salt by solution in some areas."

Also in Ohio, Clifford (1973, p. 6) states:

"The rugged line marking the southern limit of the $B$ salt results in part from subaqueous erosion or resolution... The irregular pinchout in northern Ashtabula 
county, on the other hand, may result from much later solution of the salt beds, producing collapse of overlying beds. The $B$ salt is absent in well P-90, Conneaut Township, yet is present less than a mile and half to the north in well P-167. The first well is 86 feet lower than the second at the top of the A unit and 118 feet lower at G-unit level, the difference being about equal to the amount of salt which by regional considerations seems to be missing. A similar situation in Pierce Field, located just a few miles to the east in Erie County, Pennsylvania, has been interpreted by Kelley and McGlade (1969) as evidence for solution collapse."

In sum, drilling records indicate that except near the basin margins the salt beds are solid and noncavernous where they have been extensively drilled for mining or brining purposes. This evidence suggests that in most areas where the salt beds are relatively deep, away from the effects of shallow ground-water circulation, they have not undergone significant dissolutioning. The principal brine movement is assumed to be in the permeable zones in the direction of the hydraulic gradient. If the brines move through the salt beds the movement may be slow enough, in combination with the saturated or near-saturated state of the water, to preclude significant dissolution of the salt.

\section{AREAS SUGGESTED FOR ADDITIONAL INVESTIGATION}

Shown in figures 3,6 and 9 are areas in Michigan, Ohio, and New York where conditions appear to warrant detailed studies, including test drilling, to determine the suitability of the salt beds for the burial of nuclear wastes. In these areas the beds are shallower than 3000 feet and are relatively thick, both individually and in the aggregate.

Although the suggested areas are, in general, sparsely populated with respect to nearby areas, most contain small towns, villages, farms, and suburban homes. Railroads are reasonably accessible to most parts of the areas, as are al1-weather roads. 
Oil and gas wells, including wells and test holes that have been plugged and abandoned, are probably present in the areas suggested for further study. It is probable that unplugged wells exist, abandoned and unrecorded. A field search for such wells would be imperative before sites are selected for test drilling or mining.

In Michigan two areas in the southern peninsula may warrant additional investigation of the characteristics of the salt beds. One area is in the northern part of the southern peninsula, centering in Presque Isle and northern Alpena counties; the other is in the southern part of the southern peninsula, centering in Oakland, Macomb, and st. Clair Counties. Figure 3 shows the location of these areas, and aggregate thickness of all evaporite beds greater than 10 feet thick in the Salina Formation.

The section, figure 4, shows the geologic relations of the salt beds in presque Isle and Alpena counties, where evaporites, consisting of salt, gypsum, and anhydrite, of the F, B, and A units, are several hundred feet in aggregate thickness. The individual evaporite layers are separated by beds of shale, shaley dolomite, and anhydrite.

A geologic section of the salt beds in Dakland, Macomb, and St. Clair counties, is shown in figure 5. Here too, the evaporite beds have aggregate thicknesses of a few hundred to several hundred feet. There are no faults or other structural features reported in either the northern or southern area of interest, though the Howell anticline traverses the southwest corner of Dakland county, near the southern area.

Ground water in the northern suggested study area is available generally from thick deposits of glacial sand and gravel and from bedrock (Twenter, $1966 \mathrm{a}, \mathrm{b}$ ). In some areas, however, bedrock aquifers, though capable of yielding moderate quantities of water to wells, are deeply buried and not generally used for water supplies.

In the southern area small (10 gal/min) to large (500 gal/min) water supplies are available from the glacial deposits. The bedrock aquifers are less productive and may yield water of poor quality. 


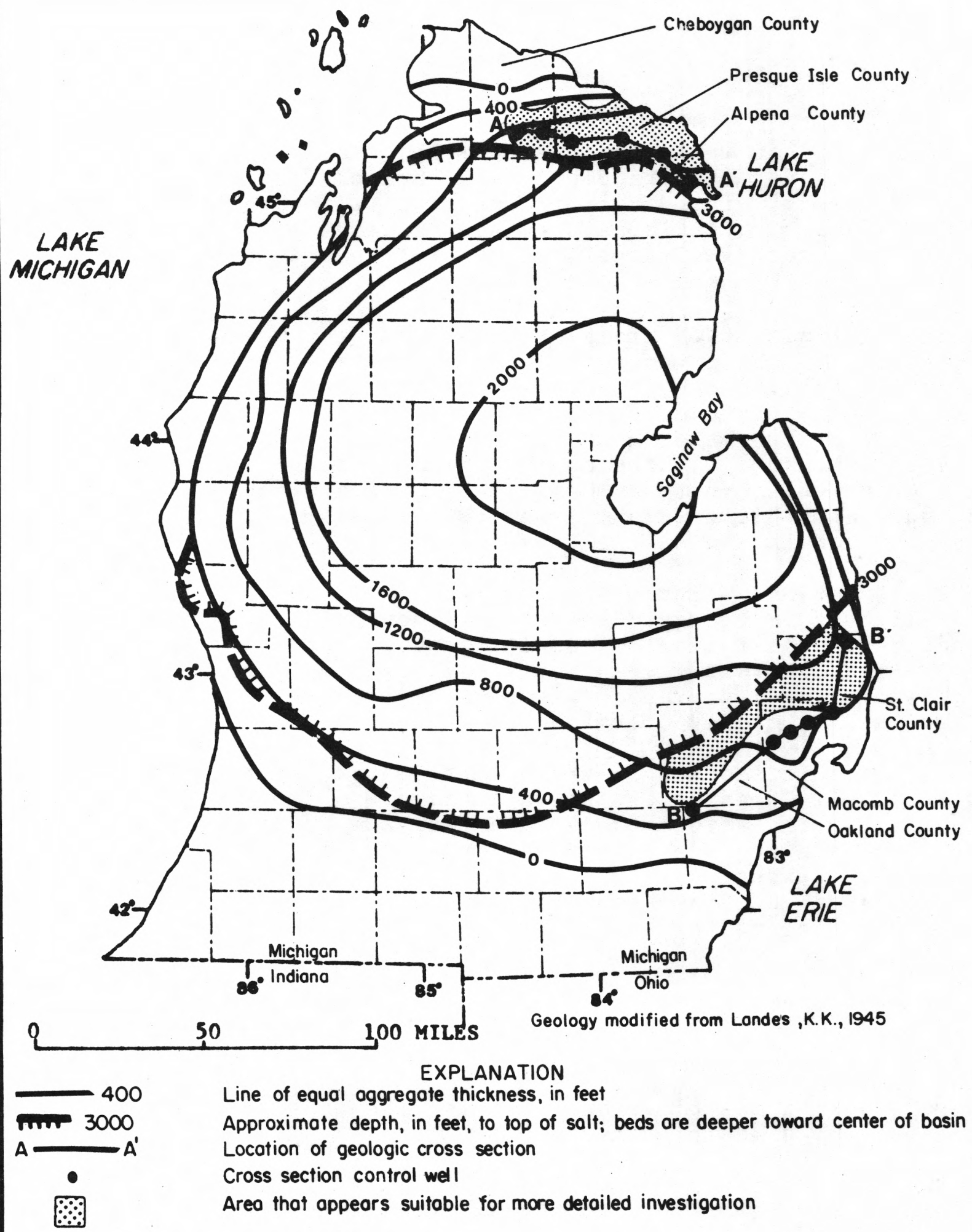

Figure 3.--Aggregate thickness of salt, gypsum, and anhydrite beds in the Salina Formation in Michigan. 


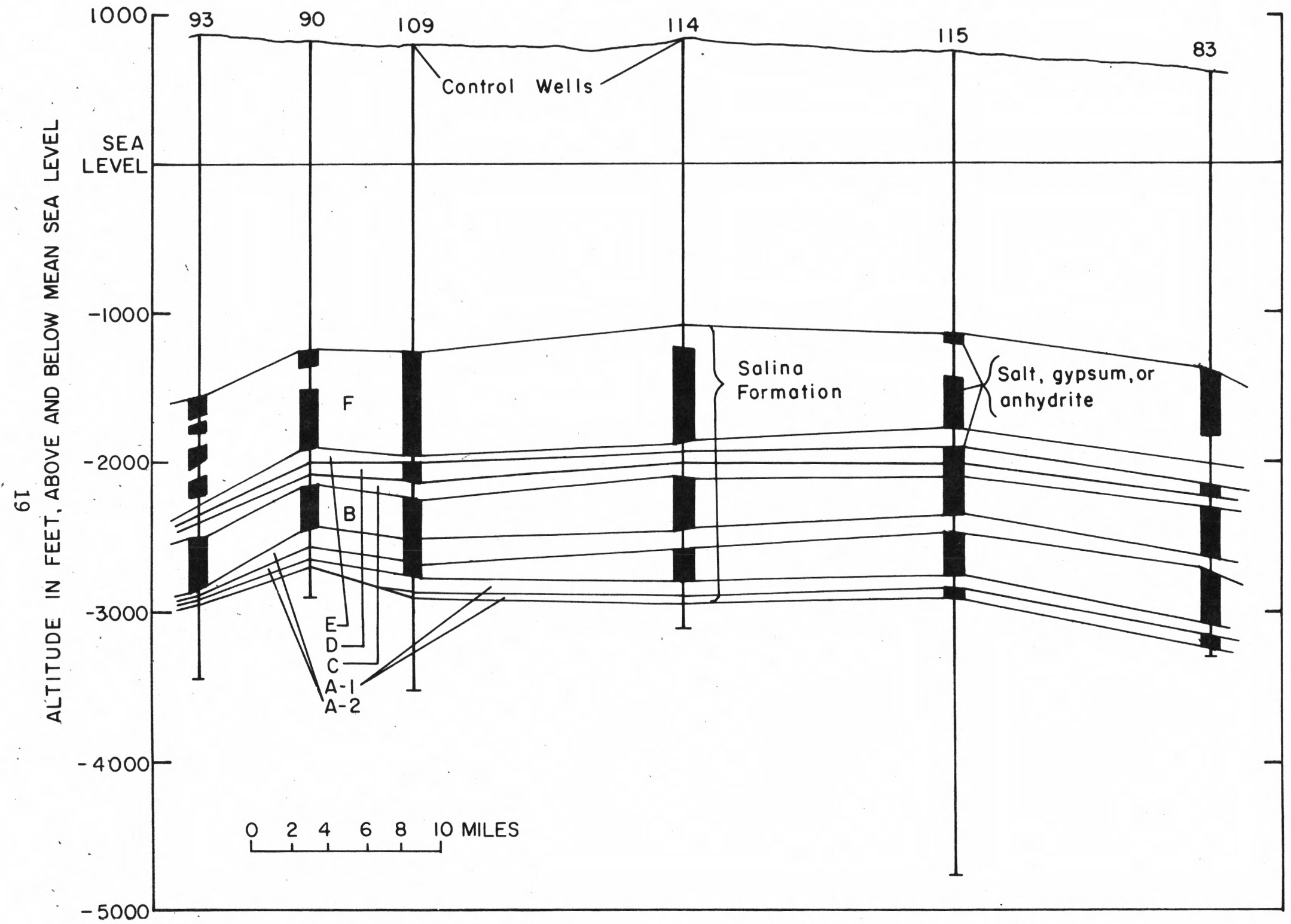

Figure 4.--Geologic section in the northern part of the southern peninsula of Michigan showing occurrence of evaporites in the Salina Formation. A-1, A-2, B, etc. designate subdivisions of the Saline Formation; location of cross section shown in fig. 3 . 


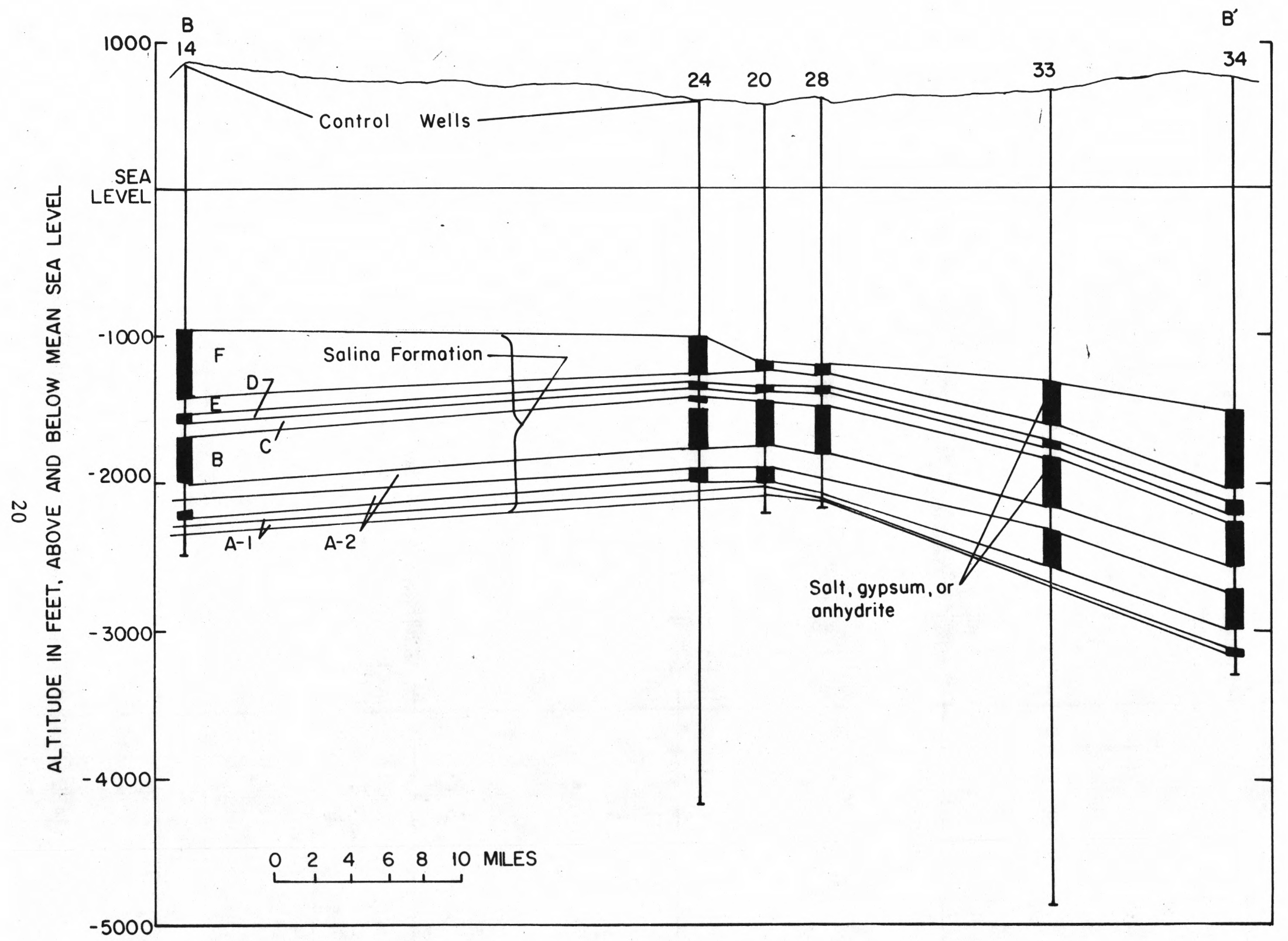

Figure 5.--Geologic section in southern Michigan showing occurrence of evaporites in the Salina Formation. A-1, A-2, B, etc. designate subdivisions of the Salina Formation; location of cross section shown in fig. 3 . 
Figure 6 shows an area suggested for additional investigation in northeast ohio. Containing about 250 square miles, the area includes most of the eastern half of Lake county and extends eastward into Ashtabula county and southward into Geauga County. Stratigraphic features of the salt beds in or near the suggested area are shown by geologic sections in figures 7 and 8 . Salts of the $p$ unit are the most prominent salts, with local thicknesses of 40 or more feet for individual beds. Salts of the $B$ and $D$ unit also are present. Aggregate salt thickness is more than 200 feet in places.

Ground-water supplies in most of the suggested study area are from bedrock aquifers because the overlying unconsolidated deposits are generally thin and consist chiefly of till and lake sediments. There are no deeply buried bedrock valleys, and only locally, such as in western Montville Township, in eastern Geauga County, do the glacial deposits approach 100 feet in thickness.

The chief aquifers in northeastern Geauga ccunty are the Mississippian Berea Sandstone (reported yields range from 7 to $30 \mathrm{gal} / \mathrm{min}$ ), the Pennsylvanian sharon member of the Pottsville Formation, and sandstones of the Mississippian Cuyahoga Group, listed in order of their importance. In Thompson Township, the northernmost township in Geauga County, Baker (1964) reports that the shales beneath the Berea Sandstone also are good sources of water for domestic wells, with two such wells having reported yields of 12 to $15 \mathrm{gal} / \mathrm{min}$ each.

In southeastern Lake county the principal aquifers are the Berea Sandstone and sandstones of the Cuyahoga Group. Yields to wells are adequate for domestic use and probably for limited commercial use in places. The remainder of lake County, and northwestern Ashtabula county, is underlain by thick shales beneath a thin cover of lake clay and till. Wells commonly yield less than 2 to 3 gal/min from the shale, the water usually coming from cracks and joints within the weathered zone.

In western New York conditions appear generally favorable for additional investigation in parts of the following counties: Steuben, Schuyler, Seneca, Cayuga, Tompkins, Cortland, and Chenango. Suggested specifically is 


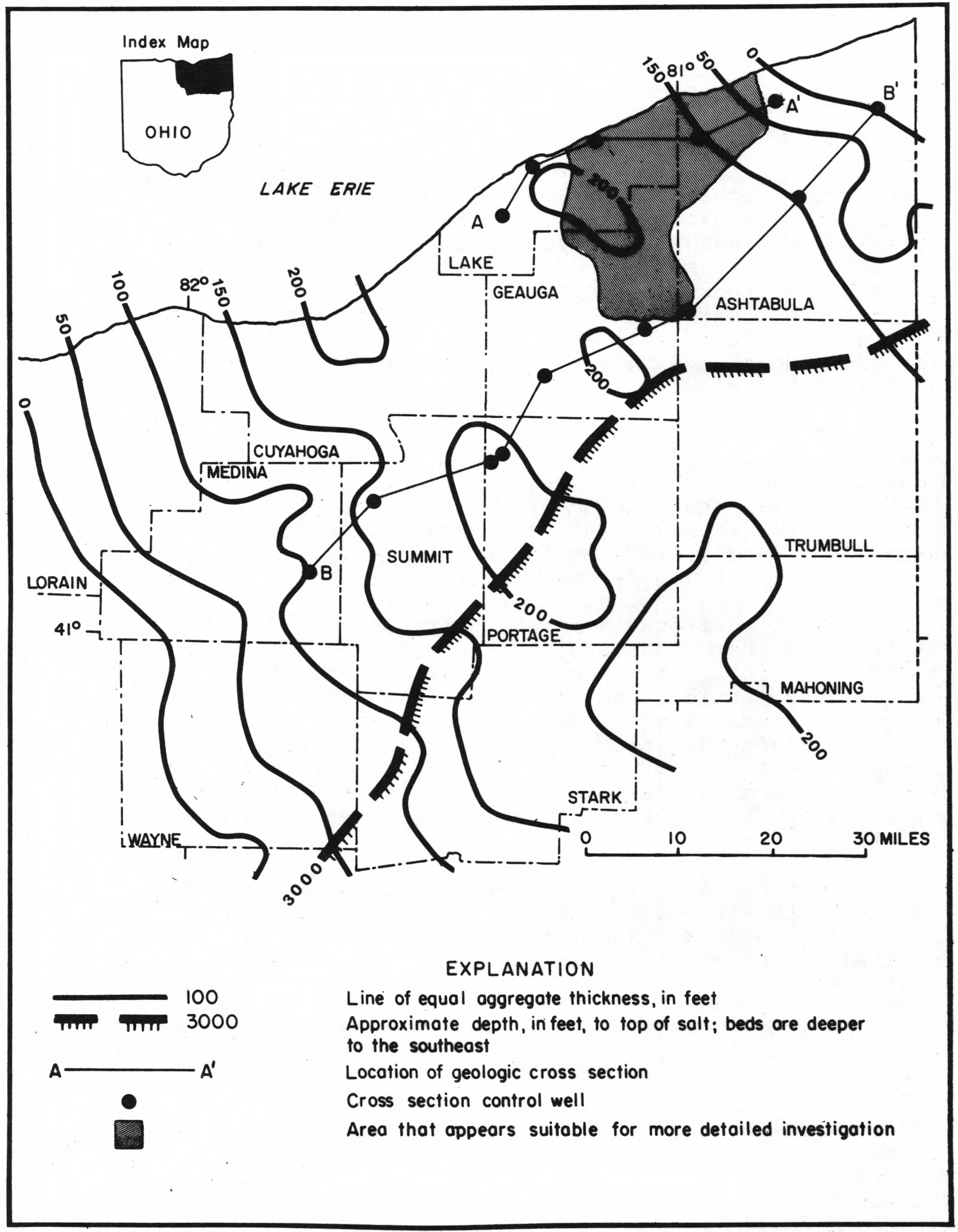

Figure 6.--Aggregate thickness of salt beds in the Salina Formation in northeast Ohio. 


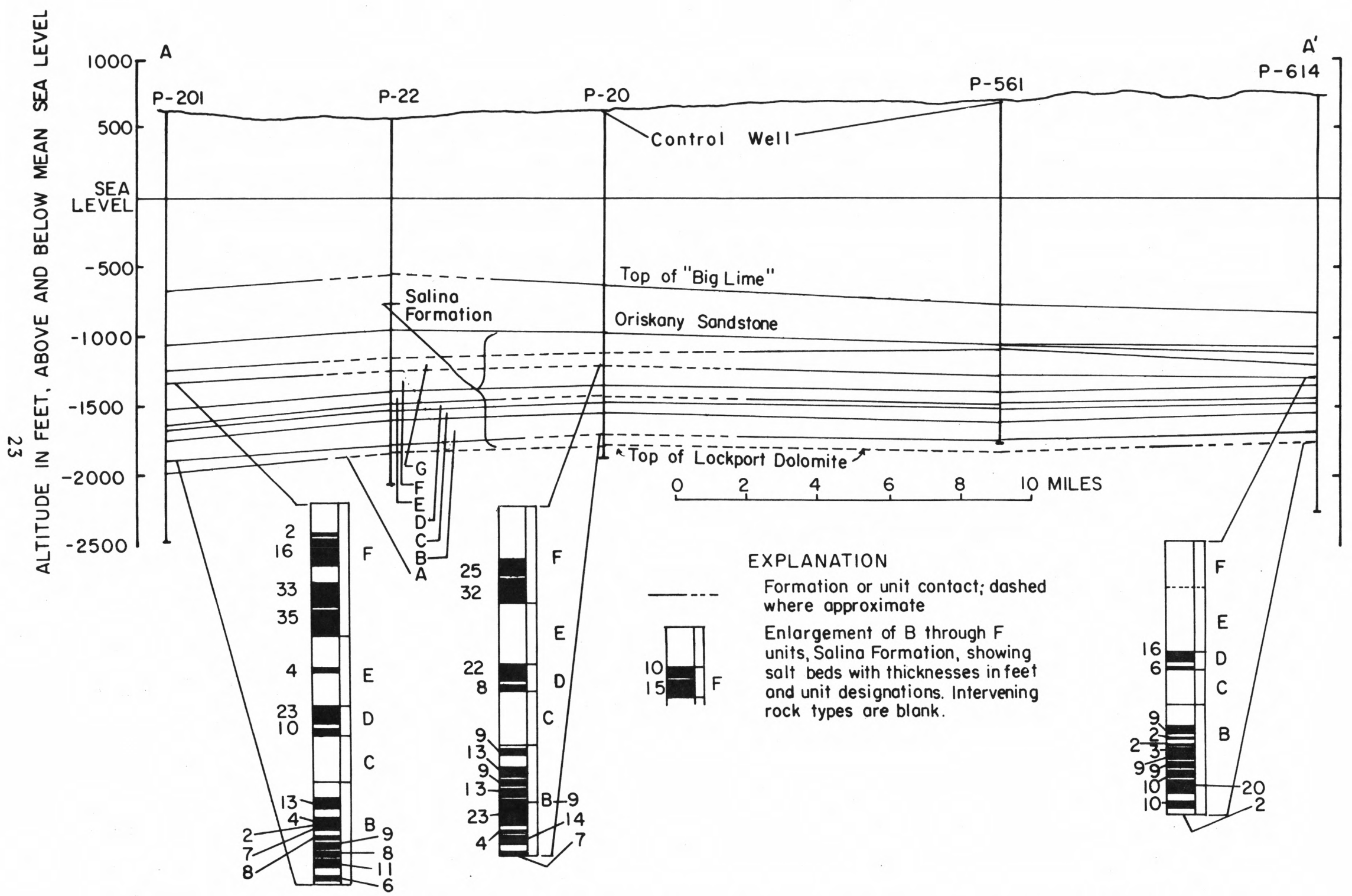

Figure 7.--Geologic section A-A' in Lake and Ashtabula Counties, Ohio, showing Salina Formation and associated strata. (See fig. 6 for cross section location.) 


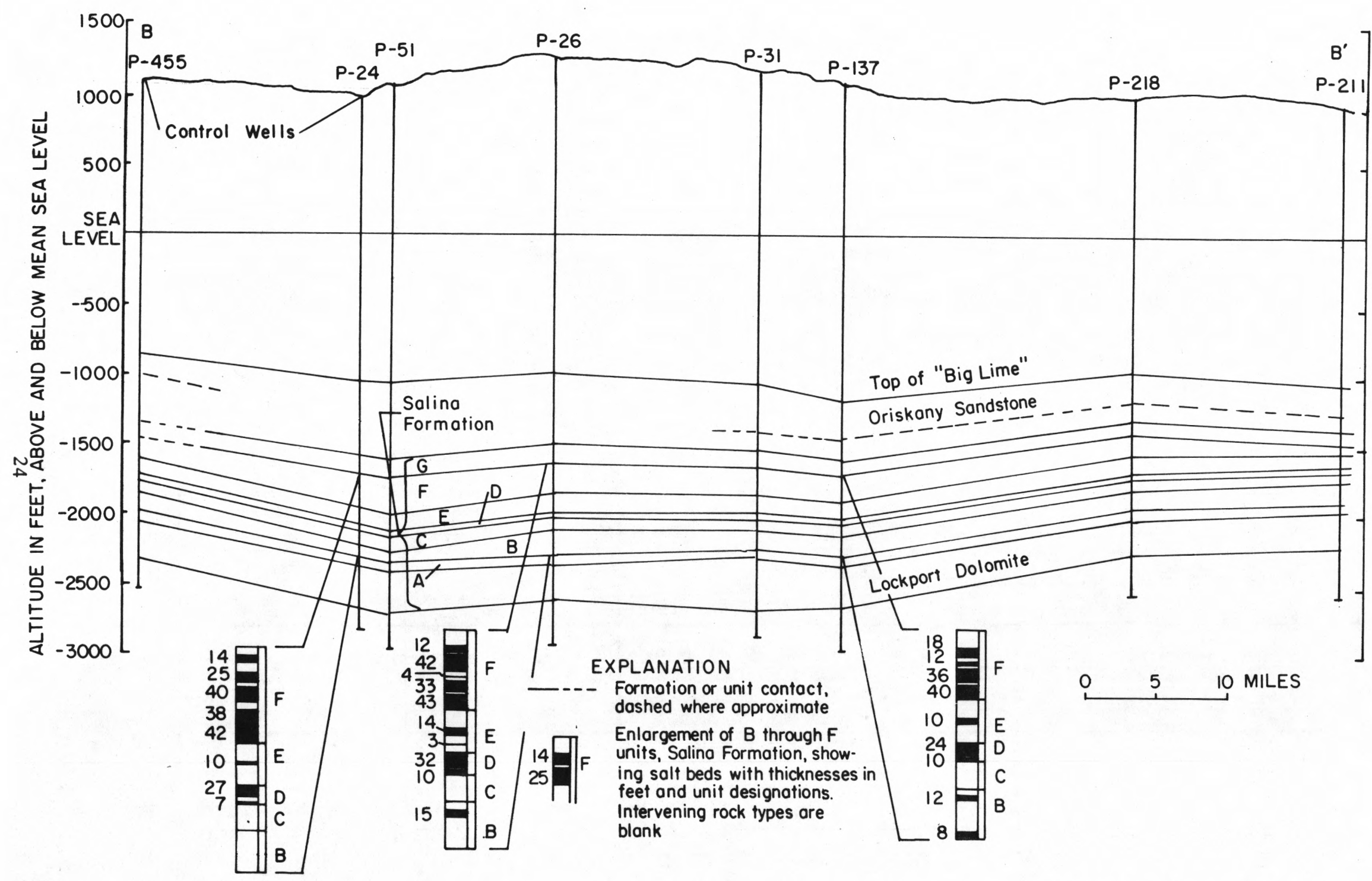

Figure 8.--Geologic section B-B' from Medina to Ashtabula Counties, Ohio, showing Salina Formation and associated strata. (See fig. 6 for cross section location.) 
an area of approximately 900 square miles that includes most of Schuyler and Tompkins counties, and extends into western cortland county and parts of Yates, Seneca, and Cayuga counties (fig. 9).

The suggested study area is underlain by relatively thick $F$ unit salts and by thinner $D$ and $E$ salts. Individual salt beds in the $F$ unit are as much as 75 to 100 feet thick, and the total aggregate salt thickness ranges from about 225 to nearly 800 feet. The stratigraphy of the salt deposits is shown by the sections in figures 10 and 11 .

Ground water in quantities sufficient for municipal and industrial use is avalable in all the principal valleys in the area, from sand and gravel in the glacial outwash. Wells yielding 500 gal/min or more have been developed from this source at cortland and at other cities. In upland areas bedrock wells are common, typically penetrating a shallow cover of till. Water also is obtained from dug wells in the till, that may tap minor inclusions of sand and gravel, and from springs. Yields are relatively small, though generally sufficient for farm and domestic use. 


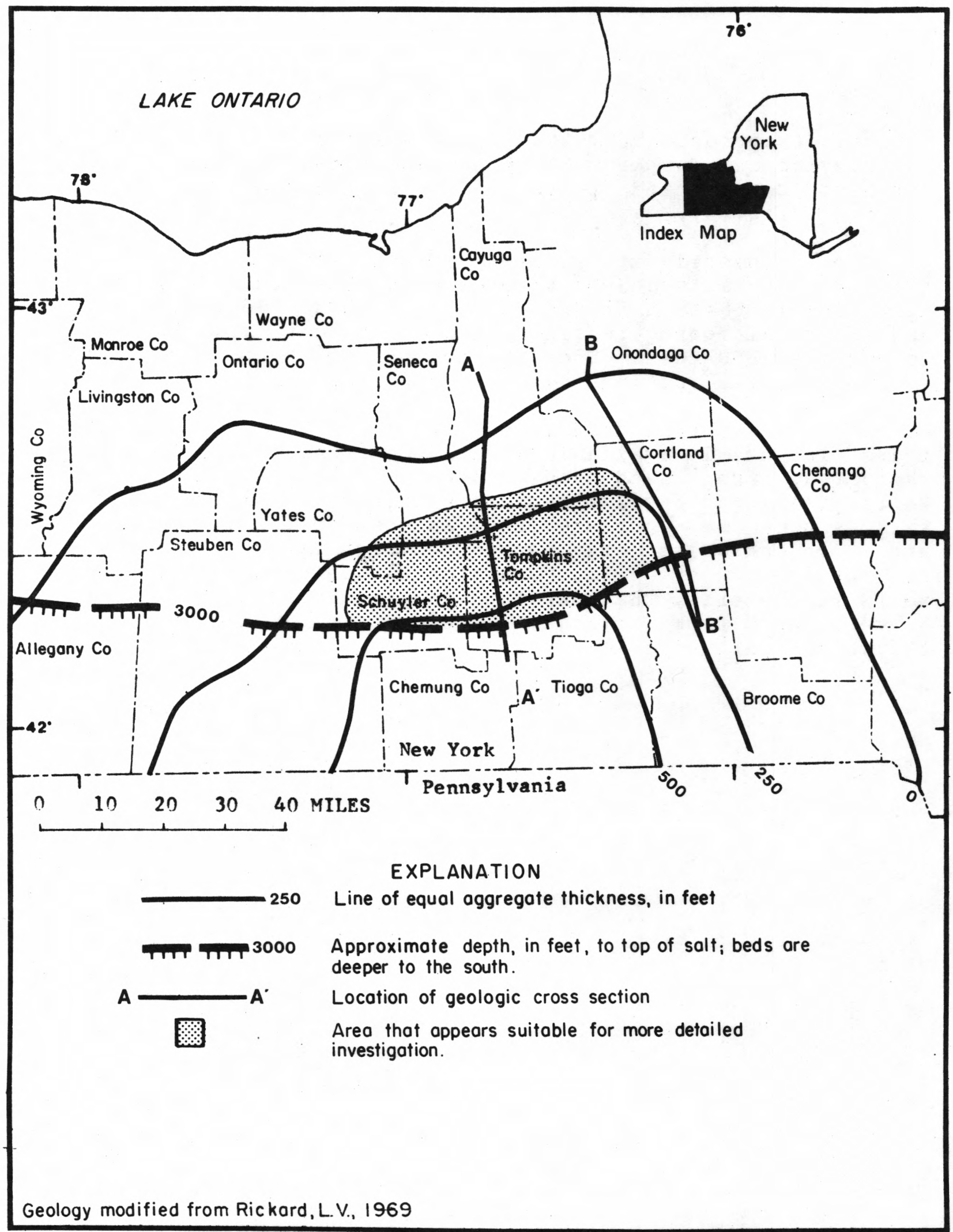

Figure 9.--Aggregate thickness of salt beds in the Syracuse salt of the Salina Group in western New York. 


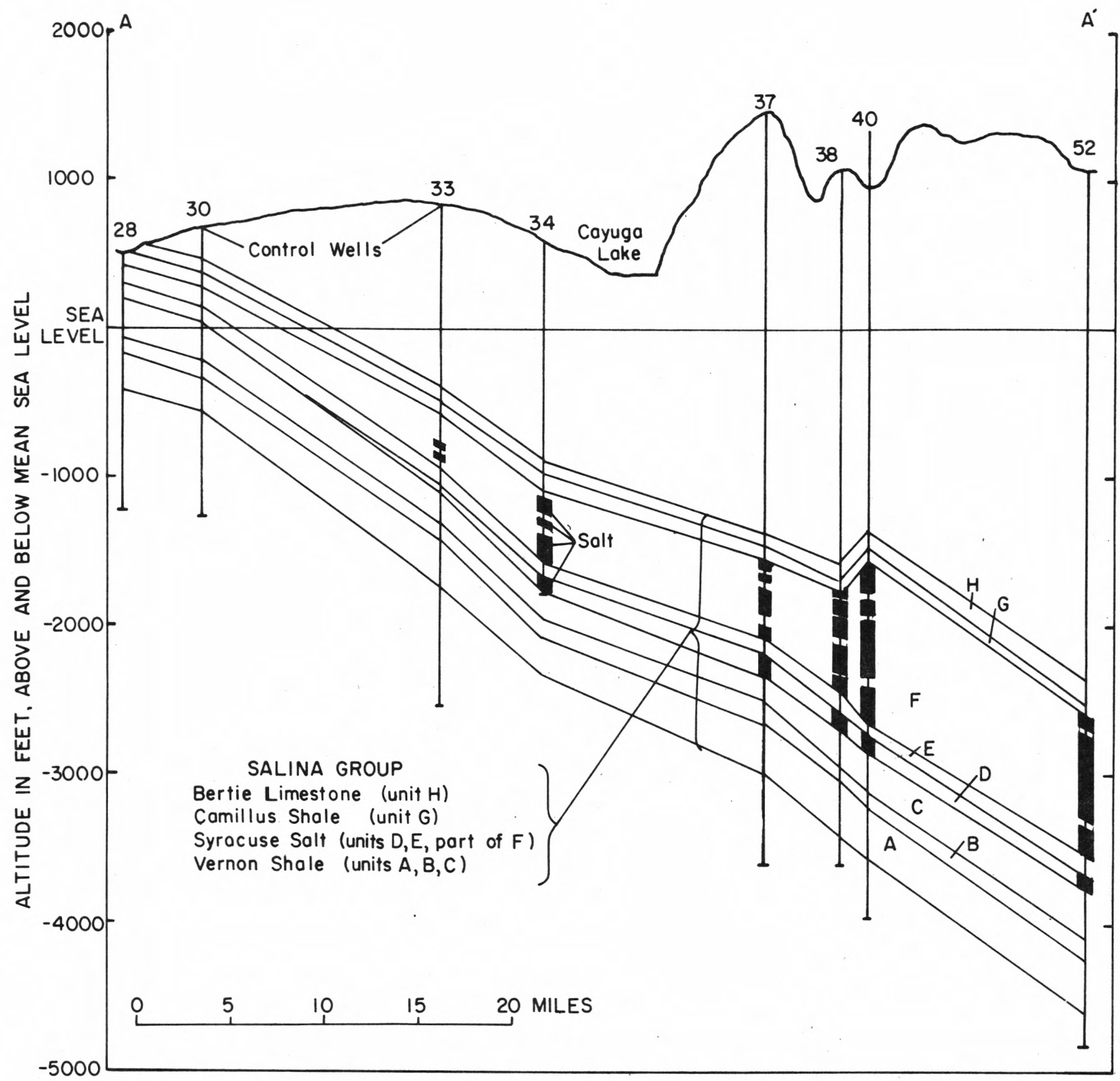

Figure 10.--Geologic section from Cayuga to Tioga Counties, New York, showing beds in the Salina Group. (See fig. 9 for location of cross section.) 


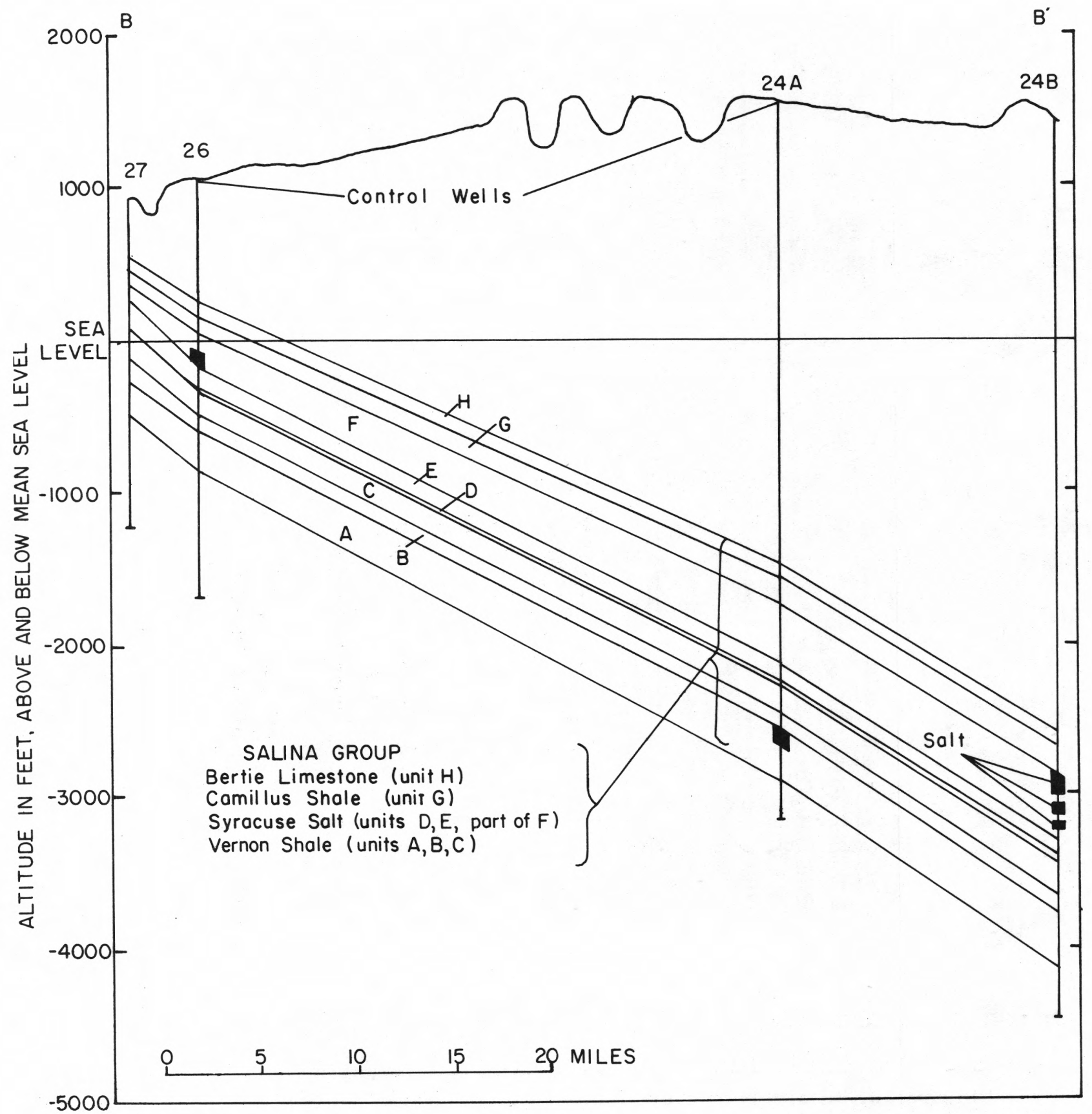

Figure 11.--Geologic section in Onondaga, Cortland, and Broome Counties, New York, showing salt beds in the Salina Group. (See fig. 9 for location of cross section.) 


\section{REFERENCES}

Baker, Jack, 1964, Geology and ground-water resources of Geauga County, Ohio: U.S. Geol. Survey open-file report prepared in cooperation with the Ohio Dept. Nat. Resources, Division of Water.

Bredehoeft, J. D., Blyth, C. R., White, W. A., and Maxey, G. B., 1963, Possible mechanism for concentration of brines in subsurface formations: Am. Assoc. Petroleum Geologists Bull., v. 47, no. 2, p. 257-269.

Clayton, R. N., Friedman, I., Graf, D. L., Mayeda, T. K., Meents, W. F., and Shimp, N. F., 1966, The origin of saline formation waters; 1. Isotopic composition: Geophysical Research Jour., v. 71, no. 16, p. 3869-3882.

Clifford, M. J., 1972, Role of the Silurian salt in discordance between deep and shallow structure in 0hio: Am. Assoc. Petroleum Geologists Bull.. v. 56, no. 10, Oct. 1972, p. 2107-2108.

1973. Silurian rock salt in Ohio: Ohio Dept. Nat. Resources, Div. Geol. Survey Rept. Inv. RI-90, 42 p., 21 figs., 4 pls., 5 tables.

1975, Subsurface liquid-waste injection in Ohio: Ohio Dept. Nat. Resources, Div. Geol. Survey Inf. Circ. 43, $27 \mathrm{p}$.

Ells, G. D., 1967, Michigan's Silurian oil and gas pools: Michigan Geol. Survey Rept. Inv. 2, 49 p.

1969. Architecture of the Michigan basin, in Studies of the Precambrian of the Michigan basin: Michigan Basin Geol. Soc. Ann. Excursion Guidebook, p. 60-88.

Frank, G. W., 1963, Salt intrusion in northeastern Ohio: Ohio Jour Science, v. 63 , no. 2 , p. 55-59, illus.

Jacoby, C. H., 1970, Faults in salt mines-their impact on operations: 3rd symposium on salt, Northern Ohio Geol. Soc.. v. 2, p. 447-452. 
Janssens, A., 1977, Dil and gas in Ohio - past, present, and future: in Seminar on industrial self-help programs for natural gas supplies: Ohio Geol. Soc., Special Publication, p. 3-25.

Johnston, R. H., 1964, Ground water in the Niagara Falls area, New York, with emphasis on the water-bearing characteristics of the bedrock: New York Conservation Dept., Water Resources Commission, Bull. GW-53, 93 p.

Kelley, D. R., and McGlade, W. G., 1969, Medina and Oriskany production along the shore of Lake Erie, Pierce Field, Erie County, Pennsylvania: Pennsylvania Geol. Survey Bull. M60, $37 \mathrm{p}$.

Lamborn, R. E., 1952, Additional analyses of brines from Ohio: Ohio Dept. Nat. Resources, Div. Geol. Survey Rept. Inv., no. 11, 56 p.

Landes, K. K., 1945, The Salina and Bass Islands rocks in the Michigan basin: U.S. Geol. Survey Oil and Gas Inv. Prelim. Map 40.

1959, The Mackinac breccia, in Geology of Mackinac Island and Lower and Middle Devonian south of the Straits of Mackinac: Michigan Basin Geol. Soc. Ann. Excursion Guidebook, p. 19-24.

Pierce, W. G. and Rich E. I., 1962, Summary of rock salt deposits in the onited States as possible storage sites for radioactive waste materials: U.S. Geol. Survey Bull. 1148, $91 \mathrm{p}$.

Piper, A. M., 1972, Regional ground-water hydrology of the southern peninsula of Michigan and of certain districts in New York and Ohio: unpublished report submitted to Union Carbide Corp., Oak Ridge National Lab., under subcontract $3745,47 \mathrm{p}$.

Rickard, L. V.. 1969, Stratigraphy of the Upper Silurian Salina Group, New York, Pennsylvania, Ohio, Ontario: New York State Mus. and Sci. Service llap and Chart Ser. 12. 57 p.. 14 pls. 
Stehli, F. G., Namy, J. H., Aten, M. D., 1963, Evaporate (evaporite) facies in northwestern (northeastern) Ohio, in symposium on salt, Cleveland, 1962: Cleveland, Ohio, Northern Ohio Geol. Soc.. p. 31-46, illus.

Stout, W., Lamborn, R. E., Schaaf, D., 1932, "Brines of Ohio": Ohio Geol. Survey, 4th Ser. Bull. 37, 123 p.

Twenter, F. R., 1966a, General availability of ground water in the glacial deposits in Michigan (map): Michigan Resources Planning Div. and Michigan Water Resources Comm .

1966b, General availability and quality of ground water in the bedrock deposits in Michigan (map): Michigan Resources Planning Div. and Michigan Water Resouces Comm.

Van Tyne, A. M., 1977, subsurface investigation of the Clarendon - Linden structure, western New York: New York State Mus, and Sci. Service open-file report, Item 3,12 p., 4 pls.

מU.S. GOVERNMENT PRINTING OFFICE: 1978-760-391/2 

